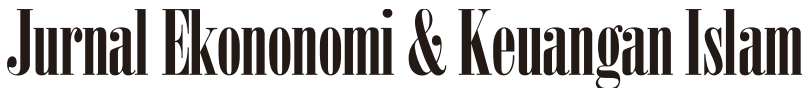

\author{
Available at http://journal.uii.ac.id/index.php/jeki
}

\section{Analisis efisiensi asuransi syariah di Indonesia tahun 2014-2016 dengan metode Data Envelopment Analysis (DEA)}

\author{
Sunarsih $^{1}$, Fitriyani ${ }^{2}$ \\ ${ }^{1}$ Prodi Manajemen Keuangan Syariah FEBI UIN Sunan Kalijaga, Yogyakarta, Indonesia \\ ${ }^{2}$ Alumni FEBI UIN Sunan Kalijaga, Yogyakarta, Indonesia \\ e-mail: ${ }^{1}$ Sunarsih_yusro@yahoo.com, ${ }^{2}$ fitriyanififi@gmail.com
}

\begin{tabular}{ll} 
Keywords: & Abstract \\
Efficiency, DEA, Sharia & This research aims to measure the level of efficiency of Sharia insurance in Indonesia by \\
Insurance & using Data Envelopment Analysis (DEA) method. DEA approach used in this study is the \\
\hline & intermediation approach where the inputs used are total assets, general and administrative \\
DOI: & expenses, and claim payments. While the outputs used are investment income and tabarru' \\
10.20885/JEKI.vol4.iss1.art2 & The result shows that the efficiency level of Asia Central Insurance, Mandiri Staco \\
\hline & Insurance, Mega General Insurance and Sunlife Insurance did not reach $100 \%$ during three \\
years of this study. The low efficiency level of several insurance companies in this study is & influenced by general and administrative expenses, claims payments, investment income, \\
capital investment, and collection of tabarru funds.
\end{tabular}

\begin{abstract}
Abstrak
Penelitian ini memilik tujuan untuk mengetahui tingkat efisiensi asuransi syariah di Indonesia dengan mengunakan metode Data Envelopment Analysis (DEA). Pendekatan DEA yang digunakan dalam penelitian ini adalah pendekatan intermediasi (the intermediation approach) dimana input yang digunakan adalah total aset, beban umum dan administrasi, dan pembayaran klaim. Sedangkan output yang digunakan adalah pendapatan investasi dan dana tabarru'. Penelitian ini menggunakan 19 sampel asuransi syariah yang terdaftar di OJK periode 2014 sampai 2016. Dari hasil olah data di ketahui bahwa Asuransi Central Asia, Asuransi Staco Mandiri, Asuransi Umum Mega dan Asuransi Sunlife menunjukkan tingkat efisiensi tidak dapat mencapai $100 \%$ selama tiga periode penelitian. Rendahnya tingkat efisiensi sejumlah perusahaan asuransi dalam penelitian ini dipengaruhi oleh beban umum dan administrasi, pembayaran klaim, pendapatan investasi, penanaman modal, dan penghimpunan dana tabarru'.
\end{abstract}

\section{Pendahuluan}

Asuransi syariah di Indonesia telah berkembang dengan pesat. Persaingan bisnis asuransi syariah di Indonesia kian ramai dengan bermunculannya pemain-pemain baru, baik dari asuransi jiwa maupun asuransi kerugian/umum dengan prinsip syariah. Pertumbuhan asuransi di Indonesia semakin meningkat seiring dengan tumbuhnya pemahaman masyarakat bahwa asuransi sangat penting untuk meminimalisir risiko dimasa depan.

Asuransi umum full syariah dan unit usaha syariah pada tahun 2011 berjumlah 20 perusahaan, yakni 2 asuransi umum full syariah dan 18 unit usaha syariah. Pada tahun 2012 unit usaha syariah bertambah dua perusahaan, sehingga berjumlah 22. Pada tahun 2013 dan 2014 unit usaha syariah meningkat jumlahnya menjadi 26 perusahaan. Kemudian pada tahun 2015, asuransi umum full syariah bertambah satu dan unit usaha syariah juga bertambah satu sehingga berjumlah 28 perusahaan. Pada tahun 2016 satu unit usaha syariah melakukan spin off ke asuransi umum full syariah sehingga asuransi umum full syariah meningkat menjadi empat. Total jumlah perusahaan asuransi umum full syariah dan unit usaha syariah pada tahun 2016 yakni 28 perusahaan. (OJK, 2016).

Peraturan pemerintah mengenai modal minimum asuransi, serta rencana beberapa perusahaan asuransi syariah untuk melakukan spin-off sesuai peraturan undang-undang tentang perasuransian. Maka, dapat diprediksi bahwa hingga tahun-tahun kedepan jumlah asuransi syariah akan terus bertambah (Outlook Asuransi Syariah, 2017). Asosiasi Asuransi Syariah Indonesia (AASI) menilai bahwa industri asuransi syariah memiliki peluang untuk menembus pangsa pasar 5,0 persen. Potensi ini didukung dengan peran regulator dan industri keuangan yang mendorong industri asuransi lebih berkembang.

Dalam rangka mendorong pertumbuhan pangsa pasar asuransi syariah, OJK mendorong pelaku industri asuransi untuk mempercepat realisasi pemisahan atau spin off unit usaha syariah. Seperti diketahui dalam UU No 
40 tahun 2014 tentang perasuransian, disebutkan bahwa perusahaan asuransi atau perusahaan reasuransi yang memiliki unit usaha syariah dengan nilai tabarru' dan dana investasi peserta telah mencapai paling sedikit 50\%, maka diwajibkan melakukan pemisahan unit usaha syariah selambat-lambatnya 10 tahun sejak UU tersebut diundangkan atau selambat-lambatnya pada akhir 2024.

Supaya pelaksanaan spin off lebih cepat dengan memenuhi persyaratan, maka unit usaha syariah harus berusaha meningkatkan daya saing dan kualitas mengingat pangsa pasar asuransi syariah yang masih fluktuatif. Oleh karena itu diperlukan analisis efisiensi secara berkala untuk mengevaluasi dan meminimalisir kesalahan dalam menentukan keputusan yang nantinya akan membuat kinerja perusahaan meningkat. Analisis efisiensi juga berguna untuk mengetahui kemampuan manajerial perusahaan dalam mengelola perusahaannya.

Efisiensi merupakan suatu hal penting dalam industri atau perusahaan. Pengukuran efisiensi dalam industri asuransi baik konvensional dan syariah juga menjadi suatu yang urgent melihat adanya persaingan yang ketat di dalam industri perasuransian Indonesia. Hal ini terlihat pula dari adanya peningkatan jumlah perusahaan asuransi jiwa maupun umum yang berdiri di Indonesia. Oleh karena itu, dengan pengukuran efisiensi pada asuransi syariah dapat menjadi suatu indikator penting dalam melihat kemampuan industri asuransi syariah untuk bertahan dan menghadapi persaingan yang ketat hingga akhirnya dapat membantu pertumbuhan ekonomi Indonesia (Purwanti, 2016).

Menurut Antonio et al. (2013) pengukuran efisiensi sangat diperlukan untuk mengevaluasi kinerja industri asuransi syariah dan akan menentukan daya saing industri tersebut. Studi di Gulf Cooperation Council (GCC) menyatakan bahwa industri asuransi syariah memiliki tingkat efisiensi teknis dan efisiensi teknis murni yang cukup tinggi, namun tingkat efisiensi biaya sedang dan masih bisa ditingkatkan lagi (Al-Amri 2015). Di sisi lain adanya studi komparatif yang dilakukan Saad et al (2007) menunjukkan bahwa secara umum efisiensi perusahaan asuransi syariah masih berada di bawah asuransi konvensional.

Abidin dan Cabanda (2009) yang melakukan penelitian pada 23 perusahaan asuransi non jiwa pada periode 2005-2007 yang membuktikan bahwa perusahaan asuransi yang lebih besar lebih efisien dibanding perusahaan asuransi yang kecil. Penelitian yang dilakukan oleh Sabiti, et al (2017) pada 14 perusahaan asuransi syariah dan 12 perusahaan asuransi umum syariah pada periode 2013-2015. Metode yang digunakan DEA dengan tiga variabel input yaitu aset, beban, pembayaran klaim dan dua variabel output yaitu pendapatan dan dana tabarru' yang diperoleh. hasil menunjukkan bahwa perusahaan asuransi jiwa syariah dan asuransi umum syariah di Indonesia belum mencapai tingkat efisien.

Teori efisiensi erat kaitannya dengan teori konsumsi dan teori produksi dalam ekonomi mikro. Efisiensi dalam teori konsumsi yaitu dimana konsumen memiliki kemampuan untuk memaksimalkan utilitas atau kepuasan yang akan dipenuhinya. Sedangkan dalam teori produksi yaitu dimana suatu perusahaan dapat menghasilkan laba yang maksimal atas produksi yang dilakukan. Efisiensi akan optimal apabila perusahaan dapat memaksimalkan output dengan menggunakan input yang tetap ataupun dengan meminimalkan penggunaan input untuk mencapai tingkat output yang sama (Karim, 2007).

Berkaitan dengan efisiensi pada teori produksi, dikenal adanya garis Frontier produksi. Dimana garis ini menggambarkan hubungan antara variabel input dan output dalam suatu proses produksi. Garis tersebut sebagaimana ditunjukkan oleh gambar berikut:

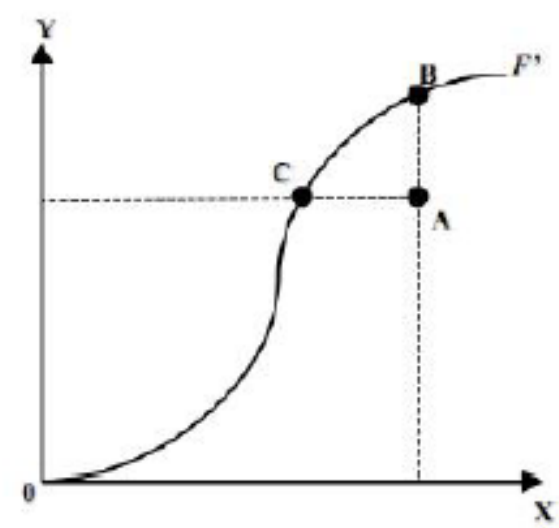

Sumber: (Coelli, Rao, O`Donnel, \& Battese, 2005 dalam Tuffahati, dkk, 2016)

Gambar 1. Garis Frontier

Garis tersebut menggambarkan bagaimana variabel output diperoleh secara maksimum dari setiap tingkatan variabel input. Dimana (x) adalah variabel input dan (y) adalah variabel output. Suatu perusahaan 
dikatakan efisien secara teknis apabila beroperasi di atas garis Frontier tersebut. Titik yang menunjukkan efisien yaitu titik B dan C. Sedangkan titik A menggambarkan inefisien, karena secara teknis sebenarnya perusahaan dapat meningkatkan output sampai dengan titik yang bersinggungan dengan titik B tanpa harus membutuhkan input yang lebih banyak. Ataupun perusahaan dapat juga memproduksi output yang tetap namun dengan menggunakan input yang lebih sedikit, seperti yang ditunjukkan oleh titik C. Sehingga produsen dapat memproduksi secara efisien dengan dua pilihan, yaitu mengurangi input atau memaksimalkan input yang ada namun dapat menghasilkan output yang lebih banyak.

Menurut Coelli et al (2005) menyebut efisiensi adalah sesuatu yang diukur dengan dua pendekatan, yaitu pendekatan yang berorientasi pada output maupun pendekatan yang berorientasi pada input. Pendekatan yang berorientasi pada output yaitu dimana suatu entitas akan memaksimalkan keuntungannya. Proporsi output yang akan dihasilkan ditingkatkan namun dengan tetap menggunakan tingkatan input yang sama. Sedangkan dalam pendekatan yang berorientasi pada input yaitu dimana entitas akan mengurangkan tingkatan proporsi input untuk menghasilkan output pada tingkatan yang sama. Dalam pendekatan ini suatu entitas akan meminimalkan biaya dengan mengurangi biaya produksinya.

\section{Efisiensi dalam pandangan islam}

Dalam teori produksi islami, mengasumsikan bahwa modal (capital) dan teknologi dalam jangka pendek diasumsikan tetap. Karena semua input yang digunakan mengandung biaya, maka prinsip dari produksi adalah bagaimana produksi dapat berjalan sehingga mampu mencapai tingkat yang paling maksimum dan efisien dengan memaksimalkan output dengan menggunakan input tettap, dan meminimalkan penggunaan input untuk mencapai tingkat output yang sama (Karim, 2007).

Agama Islam melarang berlebih-lebihan dalam segala hal, termasuk dalam memaksimalkan output. Hal ini ditakutkan akan masuk kategori perbuatan dzalim. Suatu perusahaan tidak diperkenankan untuk mencari output maksimal dari input yang minimal. Perusahaan hendaknya memperhitungkan secara cermat input dan output suatu perusahaan, agar tidak berlebih-lebihan. Larangan untuk berlebih-lebihan ini terdapat dalam firman Allah SWT:

$$
1
$$

Ayat ini jika ditinjau dari makna lahiriyahnya, maka maksud dari ayat ini adalah larangan berlebihan. Dari pembahasan di atas, dapat disimpulkan bahwa Islam membatasi pelaku ekonomi dalam menjalankan usahanya tidak menjadi penghambat untuk memperoleh keuntungan. Tidak ada definisi murni tentang efisiensi, baik itu dari segi keuntungan atau output maupun dari segi biaya atau input. Islam mengharuskan kaffah dalam menjalankan setiap aktivitas, namun dengan tidak melanggar batasan-batasan yang telah Allah SWT tentukan agar hasilnya selalu optimal dan tidak ada yang dirugikan atau terzhalimi (Tuffahati et al, 2016).

\section{Metode Penelitian}

Data Envelopment Analysis (DEA) adalah sebuah teknik pemrograman matematis yang digunakan untuk mengevaluasi efisiensi relatif dari sebuah kumpulan unit-unit pembuat keputusan decision making unit (DMU) dalam mengelola sumber daya (input) dengan jenis yang sama sehingga menjadi hasil (output) dengan jenis yang sama pula, dimana hubungan bentuk fungsi dari input ke output tidak diketahui. Istilah DMU dalam metode DEA ini dapat bermacam-macam unit, seperti bank, rumah sakit, retail store, dan apa saja yang memiliki kesamaan karakteristik operasional (Purwantoro dan Siswandi, 2006).

DEA mula-mula dikembangkan oleh Farrell (1957) yang mengukur efisiensi teknik satu input dan satu output, menjadi multi input dan multi output, menggunakan kerangka nilai efisiensi relatif sebagai rasio input (single virtual input) dengan output (single virtual output). Awalnya, DEA dipopulerkan oleh Charnes, Cooper dan Rhodes (1978) dengan metode constant return to scale (CRS) dan dikembangkan oleh Banker, Charnes, Cooper (1994) untuk variable return to scale (VRS), yang akhirnya terkenal dengan model CCR dan BCC (Sutawijaya \& Lestari, 2009).

Keunggulan Metode Data Envelopment Analysis menurut Muharam dan Pusvitasari (2007) adalah pertama, DEA dapat menangani pengukuran efisiensi secara relatif beberapa UKE (Unit Kegiatan Ekonomi) sejenis dengan menggunakan banyak input dan output. Kedua, tidak perlu mencari asumsi bentuk fungsi hubungan antara variabel input dan output dari UKE sejenis yang akan diukur efisiensinya. Ketiga, UKE-UKE dibandingkan secara langsung dengan sesamanya. Keempat, faktor input dan output dapat memiliki satuan pengukuran yang berbeda tanpa perlu melakukan perubahan satuan dari kedua variabel tersebut.

${ }^{1}$ dan janganlah kamu berlebih-lebihan. Sesungguhnya Allah tidak menyukai orang yang berlebih-lebihan (Q.S. Al-An'am: 141) 
DEA lebih memfokuskan tujuannya, yaitu mengevaluasi kinerja suatu Unit Kegiatan Ekonomi (UKE). Suatu UKE dikatakan efisien secara relatif apabila nilai dualnya sama dengan 1 (nilai efisiensi 100 persen), sebaliknya apabila nilai dualnya kurang dari 1 maka UKE bersangkutan dianggap tidak efisien secara relatif. Analisis yang dilakukan berdasarkan evaluasi terhadap efisiensi relatif dari UKE yang sebanding, selanjutnya UKE-UKE yang efisien tersebut akan membentuk garis frontier. Apabila UKE berada dalam garis frontier, UKE tersebut dapat dikatakan efisien relatif dibandingkan dengan UKE lainnya dalam sampel. DEA juga dapat menunjukkan UKE-UKE yang menjadi referensi bagi UKE-UKE yang tidak efisien (Purwanto, 2011).

Pada awalnya, DEA digunakan untuk mengatasi kekurangan yang dimiliki oleh analisis rasio dan regresi berganda. Analisis rasio hanya mampu memberikan informasi bahwa UKE tertentu yang memiliki kemampuan khusus mengkonversi satu jenis input ke satu jenis output tertentu, sedangkan analisis regresi berganda menggabungkan banyak output menjadi satu. DEA dirancang untuk mengukur efisiensi relatif suatu Unit Kegiatan Ekonomi (UKE) yang menggunakan input dan output yang lebih dari satu, di mana penggabungan tersebut tidak mungkin dilakukan (Sutawijaya \& Lestari, 2009).

Terdapat tiga pendekatan yang biasa digunakan dalam metode parametrik dan metode non-parametrik dalam mengukur hubungan antara input dan output dalam kegiatan suatu lembaga keuangan (Muharam \& Pusvitasari, 2007). Tiga pendekatan tersebut yaitu; pertama, pendekatan aset (the assets approach). Pendekatan aset menggambarkan fungsi utama suatu lembaga keuangan sebagai pemberi pinjaman. Pada pendekatan ini, output yang diukur benar-benar didefinisikan ke dalam bentuk aset. Kedua, pendekatan produksi (the production approach). Pendekatan produksi menggambarkan suatu lembaga keuangan sebagai produsen dari akun depositonya dan kredit pinjamannya, lalu mendefinisikan output sebagai jumlah tenaga kerja, pengeluaran modal pada aset tetap dan material lainnya. Dan, ketiga adalah pendekatan intermediasi (the intermediation approach). Pendekatan intermediasi menggambarkan suatu lembaga keuangan sebagai intermediator atau perantara antara unit surplus dengan unit defisit.

Dengan adanya 3 pendekatan ini, maka dalam mengukur efisiensi lembaga keuangan, keputusan untuk menentukan variabel input dan variabel output yang digunakan akan berbeda. Dalam penelitian ini menggunakan pendekatan intermediasi sebagai penentuan input dan output. Input yang digunakan dalam penelitian ini adalah total aset, beban umum dan administrasi, dan pembayaran klaim. Sedangkan outputnya adalah pendapatan investasi dan dana tabarru'.

\section{Hasil dan Pembahasan}

Teknik pengambilan sampel dalam penelitian ini dilakukan secara purposive sampling yang berarti metode pemilihan sampel dipilih berdasarkan pertimbangan (judgement sampling) yang berarti pemilihan sampel secara acak yang informasinya diperoleh dengan pertimbangan tertentu. Kriteria sampel yang digunakan adalah sebagai berikut: pertama, unit usaha syariah dalam asuransi umum syariah dan asuransi jiwa syariah yang beroperasi di Indonesia selama periode pengamatan yaitu 2014-2016. Kedua, unit usaha syariah dalam asuransi umum syariah dan asuransi jiwa syariah yang menyajikan laporan keuangan pada periode pengamatan dan telah dipublikasikan di website OJK atau website asuransi yang bersangkutan. Dan, ketiga, Unit usaha syariah dalam asuransi umum syariah dan asuransi jiwa syariah yang menyajikan laporan keuangan sesuai dengan data yang dibutuhkan peneliti.

Penelitian ini menggunakan laporan tahunan dari asuransi umum unit syariah dan asuransi jiwa unit syariah di Indonesia yaitu sembilan asuransi umum unit syariah (Asuransi Central Asia, Asuransi Adira Finance, Asuransi Jasa Raharja, Asuransi Bringin Sejahtera Arthamakmur, Asuransi Staco Mandiri, Asuransi Tugu Pratama, Asuransi Umum Mega, Asuransi Bumi Putera Muda, dan Asuransi AXA Mandiri) dan delapan asuransi jiwa unit syariah (Asuransi Great Eastern, Asuransi Manulife, Asuransi Panindai-Ichi Life, Asuransi Prudential, Asuransi Sunlife, Asuransi Tokio Marine, Asuransi Central Asia Raya Life, dan Asuransi Avrist) pada periode tahun 2014 sampai dengan tahun 2016.

\section{Efisiensi Asuransi Syariah}

Dari tabel 1 dapat diketahui bahwa tingkat efisiensi asuransi syariah cenderung fluktuatif. Terjadi peningkatan dan penurunan tingkat efisiensi setiap tahunnya. Asuransi Bringin Sejahtera Artamakmur, Asuransi Jasa Raharja, Asuransi Great Eastern, Asuransi Manulife, Asuransi Panindai-Ichi Life dan Asuransi Prudential, dari periode 2014-2016 selalu mencapai tingkat efisiensi yang stabil yaitu 100\%. Hal ini menunjukkan bahwa Asuransi Bringin Sejahtera Artamakmur, Asuransi Jasa Raharja, Asuransi Great Eastern, Asuransi Manulife, Asuransi Panindai-Ichi Life dan Asuransi Prudential sudah tidak melakukan pemborosan dalam penggunaan inputinputnya dan/atau sudah mampu memanfaatkan potensi kemampuan produksi yang dimiliki secara optimal sehingga mampu mencapai tingkat output yang efisien. 
Tabel 1. Hasil Perhitungan Efisiensi Asuransi Syariah

\begin{tabular}{llll}
\hline \multicolumn{1}{c}{ Nama Asuransi } & $\mathbf{2 0 1 4}$ & $\mathbf{2 0 1 5}$ & $\mathbf{2 0 1 6}$ \\
\hline ACA & 0.735 & 0.773 & 0.784 \\
\hline Adira & 0.608 & 0.678 & 1.000 \\
\hline Jasa Raharja & 1.000 & 1.000 & 1.000 \\
\hline BRINS & 1.000 & 1.000 & 1.000 \\
\hline Staco Mandiri & 0.630 & 0.872 & 0.925 \\
\hline Tugu Pratama & 1.000 & 1.000 & 0.410 \\
\hline Mega & 0.491 & 0.636 & 0.620 \\
\hline Bumida & 0.957 & 1.000 & 0.932 \\
\hline AXA Mandiri & 0.681 & 1.000 & 1.000 \\
\hline Great Eastern & 1.000 & 1.000 & 1.000 \\
\hline Manulife & 1.000 & 1.000 & 1.000 \\
\hline Panindai-ichi & 1.000 & 1.000 & 1.000 \\
\hline Prudential & 1.000 & 1.000 & 1.000 \\
\hline Sunlife & 0.778 & 0.707 & 0.626 \\
\hline Tokio Marine & 1.000 & 0.980 & 0.804 \\
\hline CAR Life & 0.736 & 0.864 & 1.000 \\
\hline Avrist & 1.000 & 1.000 & 0.643 \\
\hline
\end{tabular}

Pada Asuransi Central Asia, Asuransi Staco Mandiri, Asuransi Mega dan Asuransi Sunlife, selama periode penelitian belum pernah mencapai tingkat efisiensi 100\%. Rendahnya tingkat efisiensi tersebut menunjukkan bahwa Asuransi Central Asia, Asuransi Staco Mandiri, Asuransi Mega dan Asuransi Sunlife, masih melakukan pemborosan dalam penggunaan input-inputnya dan/atau belum mampu memanfaatkan potensi kemampuan produksi yang dimiliki secara optimal sehingga tidak mencapai tingkat output yang efisien. Berikut pemaparan komprehensif tingkat efisiensi masing-masing asuransi umum unit syariah dan asuransi jiwa unit syariah.

\section{Efisiensi Asuransi Umum Unit Syariah}

Dari gambar 1. dapat dilihat bahwa tingkat efisiensi Asuransi Centra Asia (ACA) bersifat fluktuatif. Artinya, Asuransi Central Asia (ACA) mengalami perubahan tingkat efisiensi selama periode penelitian. Selama tiga periode penelitian, Asuransi Central Asia (ACA) mengalami kenaikan efisiensi yang cukup signifikan tetapi tidak dapat mencapai efisiensi 100\%. Tingkat efisiensi berturut-turut pada periode 2014 sampai 2016 yakni 73,5\%, 77,3\% dan 78,4\%. Berdasarkan perhitungan DEA, ketidakefisienan Asuransi Central Asia (ACA) bersumber pada variabel input (total aset, beban umum \& administrasi, dan pembayaran klaim) dan variabel output (pendapatan investasi).

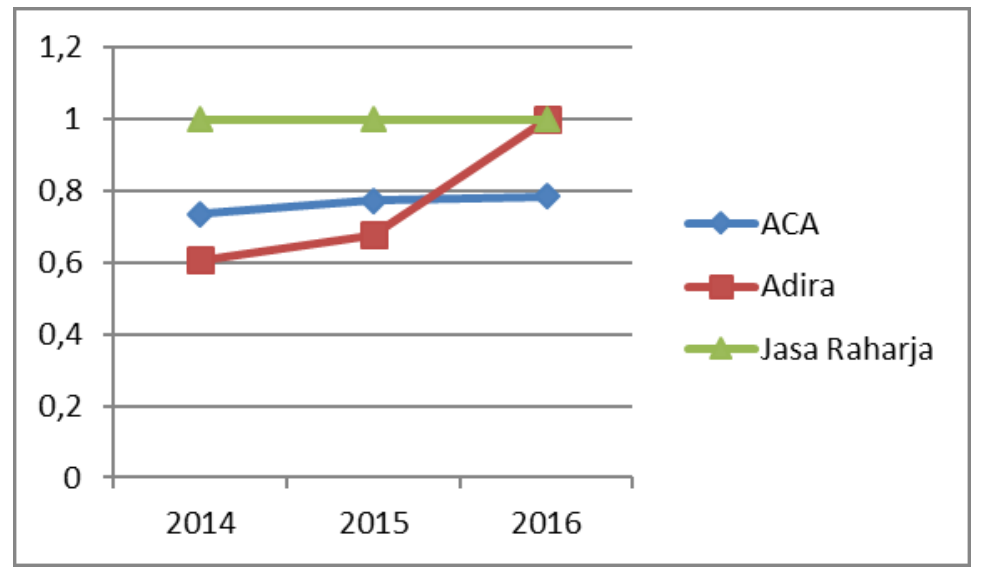

Gambar 1. Tingkat Efisiensi Asuransi Central Asia, Asuransi Adira, dan Asuransi Jasa Raharja

Asuransi Adira mengalami penurunan dan peningkatan efisiensi sehingga terjadi perubahan yang signifikan dari periode sebelumnya. Pada periode 2014 tingkat efisiensi sebesar 60,8\%. Efisiensi Asuransi Adira 
naik pada periode 2015 menjadi 67,8\%. Peningkatan yang signifikan terjadi pada periode 2016. Dari periode 2015 yang mencapai tingkat efisiensi sebesar $67,8 \%$ dan naik pada periode 2016 mencapai efisiensi $100 \%$.

Asuransi Jasa Raharja Putera telah mencapai efisien selama tiga periode penelitian dari 2014 sampai 2016. Hal ini ditunjukkan dari keseluruhan nilai dual dalam periode penelitian bernilai 1 atau $100 \%$. Nilai dual 1 atau tingkat efisiensi 100\% mengindikasikan bahwa Asuransi Jasa Raharja telah mampu mengoptimalkan seluruh sumber daya yang dimilikinya sehingga dapat menghasilkan output yang maksimal.

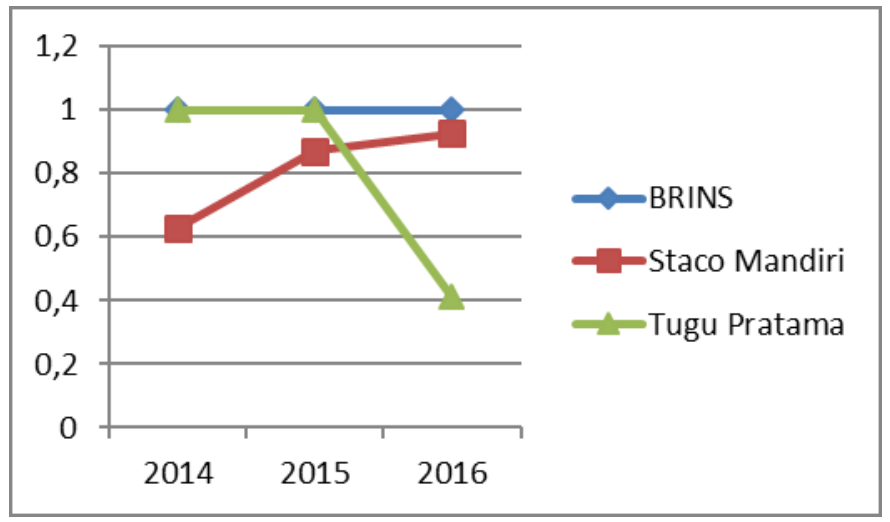

Gambar 2. Tingkat Efisiensi Asuransi BRINS, Asuransi Staco Mandiri, dan Asuransi Tugu Pratama

Asuransi Bringin Sejahtera Artamakmur (BRINS) selama periode penelitian yakni 2014, 2015 dan 2016 sudah mencapai efisien. Asuransi BRINS sudah dapat menghemat target input dan outputnya, sehingga menghasilkan aktual yang sesuai dengan target. Persamaan target dan aktual akan menghasilkan nilai efisiensi sebesar $100 \%$.

Asuransi Staco Mandiri selama tiga periode penelitian, selalu menghasilkan inefisiensi. Artinya, tidak pernah mencapai tingkat efisiensi 100\%. Meskipun Asuransi Staco Mandiri belum pernah mencapai efisiensi $100 \%$, akan tetapi, setiap periode terjadi peningkatan efisiensi. Artinya, dari ketidakefisienan tersebut, Asuransi Staco Mandiri terus mengupayakan untuk melakukan perbaikan sehingga dapat mencapai peningkatan efisiensi setiap tahunnya.

Asuransi Tugu Pratama dapat mencapai efisien pada periode 2014 dan 2015, yakni mencapai efisiensi 100\%. Sayangnya, efisiensi ini tidak konsisten dan turun drastis pada periode tahun 2016 yakni hanya 41\%. Hal ini terjadi karena kehati-hatian dalam penggunaan input dan pemborosan dalam outputnya.

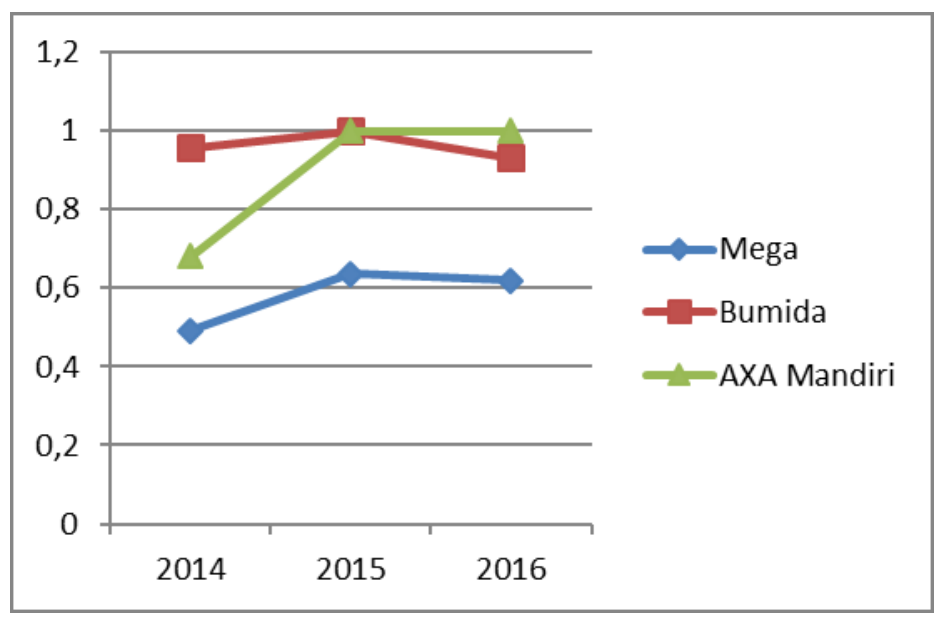

Gambar 3. Tingkat Efisiensi Asuransi Umum Mega, Asuransi Bumi Putera Muda, dan Asuransi AXA Mandiri

Dari gambar 3 diatas dapat diketahui bahwa ketiga asuransi tersebut tidak dapat mencapai efisien 100\% tiap periode penelitian. Artinya, ketiga asuransi tersebut bersifat fluktuatif. Asuransi Umum Mega, selama periode penelitian belum pernah mencapai efisiensi 100\%, jadi dapat disimpulkan bahwa Asuransi Mega selalu 
mengalami inefisiensi. Asuransi Umum Mega belum pernah mencapai efisiensi 100\%. Tetapi, Asuransi Umum Mega hampir setiap periode mengalami peningkatan efisiensi.

Asuransi Bumi Putera Muda (Bumida) juga mengalami fluktuatif. Selama periode penelitian, hanya dapat mencapai efisien bernilai dual 1 atau 100\% yaitu pada periode 2015. Asuransi Bumi Putera Muda tidak dapat mempertahankan efisiensinya pada periode selanjutnya dikarenakan mengalami inefisiensi pada ketiga inputnya (total aset, beban umum \&administrasi, dan pembayaran klaim) dan satu outputnya yaitu pendapatan investasi.

Asuransi AXA Mandiri mengalami kenaikan yang cukup signifikan dari periode 2014 sampai periode 2016. Pada periode 2014, tingkat efisiensi Asuransi AXA Mandiri yakni 68,1\%. Kenaikan yang signifikan yakni dari periode 2014 ke periode 2015, yaitu mencapai efisien 100\%. Asuransi AXA Mandiri dapat mempertahankan efisiensinya pada periode 2016.

Tabel 2. Rata-Rata Tingkat Efisiensi Asuransi Umum Unit Syariah

\begin{tabular}{lc}
\hline \multicolumn{1}{c}{ Nama Asuransi } & Rata-rata Efisiensi \\
\hline ACA & 0.764 \\
\hline Adira & 0.762 \\
\hline Jasa Raharja & 1.000 \\
\hline BRINS & 1.000 \\
\hline Staco Mandiri & 0.809 \\
\hline Tugu Pratama & 0.803 \\
\hline Mega & 0.582 \\
\hline Bumida & 0.963 \\
\hline Axa Mandiri & 0.894 \\
\hline
\end{tabular}

Rata-rata efisiensi dari asuransi umum unit syariah dari periode 2014 sampai dengan 2016 dapat dilihat pada tabel 2. Rata-rata efisiensi tertinggi diperoleh oleh Asuransi Bringin Sejahtera Artamakmur dan Asuransi Jasa Raharja yakni sebesar nilai dual 1 atau 100\% dan rata-rata efisiensi terendah dicapai oleh Asuransi Staco Mandiri yakni sebesar 58,2\%.

\section{Tingkat Efisiensi Asuransi Jiwa Unit Syariah}

Selama rentang waktu penelitian yakni tahun 2014 hingga 2016, Asuransi Great Eastern, Asuransi Manulife, Asuransi Panindai-Ichi dan Asuransi Prudential dapat menjalankan perannya sebagai lembaga intermediasi dengan baik. Hal ini dapat dilihat dari gambar 4, yang mana selama periode penelitian Asuransi Great Eastern, Asuransi Manulife, Asuransi Panindai-Ichi dan Asuransi Prudential selalu memperoleh skor/nilai dual 1 atau efisiensi $100 \%$.

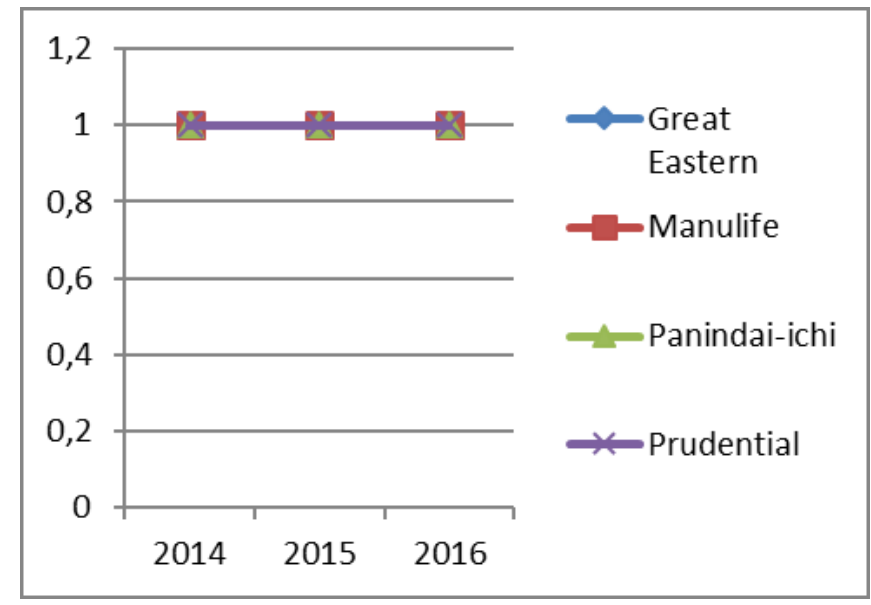

Gambar 4. Tingkat Efisiensi Asuransi Great Eastern, Asuransi Manulife, Asuransi Panindai-Ichi dan Asuransi Prudential

Asuransi Great Eastern, Asuransi Manulife, Asuransi Panindai-Ichi dan Asuransi Prudential dapat menjaga efisiensi dengan stabil. Kestabilan nilai efisiensi pada Asuransi Great Eastern, Asuransi Manulife, 
Asuransi Panindai-Ichi dan Asuransi Prudential ini, menandakan bahwa asuransi tersebut selama periode penelitian telah dapat memanfaatkan input yang dimiliki seefektif dan seefisien mungkin sehingga tidak terjadi pemborosan, dan dapat menghasilkan output yang sesuai dengan target.

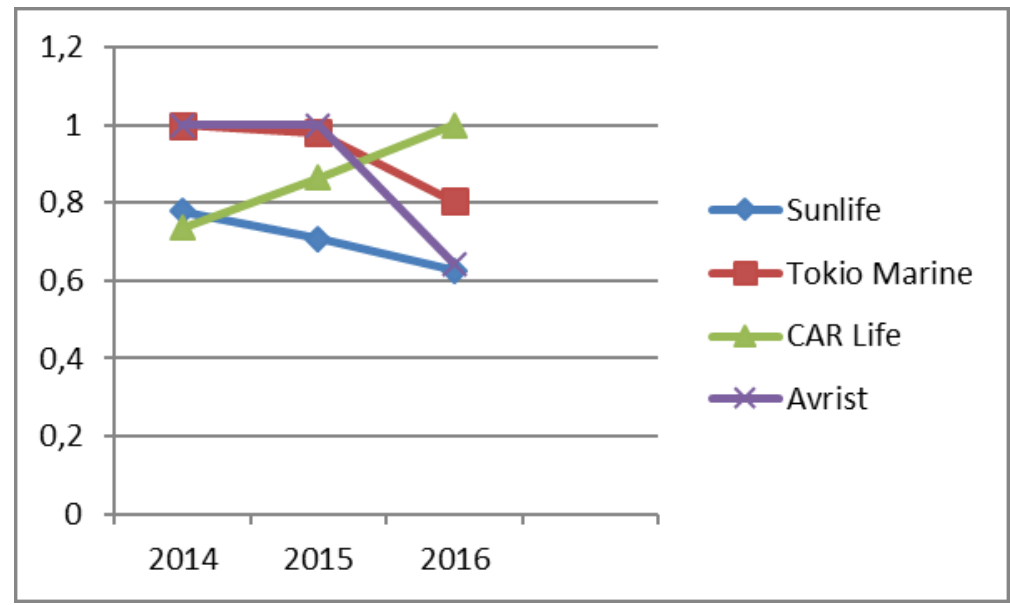

Gambar 5. Tingkat Efisiensi Asuransi Sunlife, Asuransi Tokio Marine, Asuransi CAR life dan Asuransi Avrist

Dari gambar di atas, dapat dilihat bahwa selama tiga periode penelitian, Asuransi Sunlife tidak dapat mencapai efisien 100\%. Tingkat efisiensi Asuransi Sunlife cenderung menurun tiap periodenya. Tingkat efisien paling tinggi dicapai pada periode 2014 yakni sebesar 77,8\%. Namun, terus menurun pada periode 2015 dan 2016. Tingkat efisiensi paling rendah yaitu pada periode ketiga atau tahun 2016 yaitu sebesar $62,6 \%$. Ketidakefisienan ini disebabkan karena pemborosan input. Ketiga input mengalami inefisiensi yaitu total aset, beban umum\& administrasi dan pembayaran klaim.

Asuransi Tokio Marine mencapai efisiensi 100\% pada periode 2014. Pada periode tahun 2015 mengalami inefisiensi, sehingga tingkat efisiensi hanya mencapai $98 \%$ dan pada tahun 2016 turun lagi menjadi 80,4\%. Ketidakefisiensinan ini terjadi karena aktual input yang jauh lebih sedikit daripada targetnya.

Asuransi CAR life pada tahun 2014 mencapai efisiensi sebesar 73,6\%. Dan naik pada periode 2015 menjadi 86,4\%. Ketidakefisiensinan ini diakibatkan karena kehati-hatian dalam penggunaan input dan pencapaian yang lebih besar dari target pada pendapatan investasi. Pada periode 2016 CAR life dapat mencapai efisiensi $100 \%$.

Asuransi Avrist juga tidak dapat mempertahankan efisiensinya. Pada periode 2014 dan 2015, Asuransi Avrist dapat mencapai efisiensi 100\%. Namun pada periode 2016 terjadi inefisiensi, sehingga hanya dapat mencapai efisiensi 64,3\%. Ketidakefisiensinan ini diakibatkan karena kehati-hatian dalam penggunaan input dan pencapaian yang lebih besar dari target pada dana tabarru'.

Tabel 3. Rata-Rata Tingkat Efisiensi Asuransi Jiwa Unit Syariah

\begin{tabular}{lc}
\hline \multicolumn{1}{c}{ Nama Asuransi } & Rata-rata efisiensi \\
\hline Great Eastern & 1.000 \\
\hline Manulife & 1.000 \\
\hline Panindai-Ichi & 1.000 \\
\hline Prudential & 1.000 \\
\hline Sunlife & 0.704 \\
\hline Tokio Marine & 0.928 \\
\hline Car Life & 0.900 \\
\hline Avrist & 0.881 \\
\hline
\end{tabular}

Pada tabel 3 dapat dilihat bahwa, rata-rata efisiensi Asuransi Great Eastern, Asuransi Manulife, Asuransi Panindai-Ichi dan Asuransi Prudential mencapai 100\%. Artinya keempat asuransi tersebut telah mencapai efisien. Rata-rata efisien terendah dicapai oleh Asuransi Sunlife yakni sebesar 70,4\%. 


\section{Inefisiensi Asuransi Syariah}

Dari semua sampel penelitian, hanya empat asuransi yang mengalami inefisiensi tiap periodenya, yakni Asuransi Central Asia, Asuransi Staco Mandiri, Asuransi Umum Mega dan Asuransi Sunlife. Ketidakefisien tersebut akan dijelaskan sebagai berikut,

Tabel 4 Input-Output Asuransi Central Asia pada Periode yang tidak Efisien (dalam Jutaan Rupiah)

\begin{tabular}{|c|c|c|c|c|c|c|}
\hline \multirow{2}{*}{ tahun } & \multicolumn{3}{|c|}{ Pendapatan Investasi } & \multicolumn{3}{|c|}{ Dana Tabarru } \\
\hline & Target & Aktual & Selisih & Target & Aktual & Selisih \\
\hline 2014 & 6571 & 1061 & 5510 & 18687 & 18687 & 0 \\
\hline 2015 & 6226 & 1100 & 5126 & 21360 & 21360 & 0 \\
\hline 2016 & 10574 & 1221 & 9353 & 21560 & 21560 & 0 \\
\hline \multirow{2}{*}{ tahun } & \multicolumn{3}{|c|}{ Total Aset } & \multicolumn{3}{|c|}{ Beban Umum \& Administrasi } \\
\hline & Target & Aktual & Selisih & Target & Aktual & Selisih \\
\hline 2014 & 134225 & 182687 & -48462 & 2497 & 4213 & -1716 \\
\hline 2015 & 153434 & 198474 & -45040 & 3346 & 6351 & -3005 \\
\hline 2016 & 146700 & 187076 & -40376 & 3102 & 5353 & -2251 \\
\hline \multirow{2}{*}{ tahun } & \multicolumn{6}{|c|}{ Pembayaran Klaim } \\
\hline & \multicolumn{2}{|c|}{ Target } & \multicolumn{2}{|c|}{ Aktual } & \multicolumn{2}{|c|}{ Selisih } \\
\hline 2014 & \multicolumn{2}{|c|}{12455} & \multicolumn{2}{|c|}{20768} & \multicolumn{2}{|c|}{-8313} \\
\hline 2015 & \multicolumn{2}{|c|}{12201} & \multicolumn{2}{|c|}{16297} & \multicolumn{2}{|c|}{-4096} \\
\hline 2016 & \multicolumn{2}{|c|}{7596} & \multicolumn{2}{|c|}{20329} & \multicolumn{2}{|c|}{-12733} \\
\hline
\end{tabular}

Sumber: Output DEAP 2.1 yang diolah kembali

Berdasarkan tabel 4 dapat diketahui bahwa Asuransi Central Asia mengalami inefisiensi pada ketiga inputnya (total aset, beban umum \& adminsitrasi, dan pembayaran klaim) dan satu outputnya yaitu pendapatan investasi. Dalam penelitian ini, total aset aktual pada periode 2014, 2015 dan 2016 secara berturut-turut adalah sebesar Rp182.687 juta, Rp198.474 juta, dan Rp187.076 juta. Total aset seharusnya atau targetnya secara berturutturut yaitu sebesar Rp134.225 juta, Rp153.434 juta, dan Rp146.700 juta. Secara rata-rata, Asuransi Central Asia telah mengalami pemborosan pada total aset sebesar Rp 48.462 juta, Rp 45.040 juta, dan Rp40.376 juta.

Beban umum \& administrasi pada Asuransi Central Asia juga mengalami inefisiensi. Beban umum \& administrasi aktual secara berturut-turut yakni sebesar Rp. 4.213 juta, Rp. 6.351 juta dan Rp. 5.353 juta. Adapun beban umum \& administrasi seharusnya atau targetnya yakni Rp.2.497 juta, Rp. 3.346 juta dan Rp. 3.102 juta. Artinya, Asuransi Central Asia mengalami pemborosan pada beban umum \& administrasi sebesar Rp. 1.716 juta, Rp. 3.005 juta dan Rp2.251 juta. Beban umum \& administrasi aktual yang lebih besar menunjukkan bahwa perusahaan belum mengoptimalkan dana yang disediakan beban umum \& administrasi secara optimal, sehingga terjadi pemborosan.

Input pembayaran klaim juga mengalami inefisiensi. Pembayaran klaim aktual pada periode 2014, 2015 dan 2016 secara berturut-turut adalah sebesar Rp20.768 juta, Rp16.297 juta danRp20.329 juta. Sedangkan pembayaran klaim targetnya yakni sebesar Rp12.455 juta, Rp12.201 juta dan Rp7.596 juta. Artinya, Asuransi Central Asia mengalami pemborosan pada input pembayaran klaim sebesar Rp8.313 juta, Rp4.096 juta dan Rp12.733 juta. Pembayaran klaim aktual yang lebih besar menunjukkan bahwa Asuransi Central Asia belum menggunakan dananya secara optimal, sehingga terjadi pemborosan.

Asuransi Central Asia juga mengalami inefisiensi pada salah satu outputnya yaitu pendapatan investasi. Pendapatan investasi aktual secara berturut-turut yaitu sebesar Rp1.061 juta, Rp1.100 juta danRp1.221 juta. Sedangkan pembayaran klaim seharusnya yaitu Rp6.571 juta, Rp6.226 juta dan Rp10.574 juta. Supaya pendapatan investasi pada Asuransi Central Asia dapat efisien, maka harus dinaikkan sebesar Rp5.510 juta, Rp5.126 juta dan Rp 9.353 juta. Hal ini terjadi karena Asuransi Central Asia terlalu hati-hati dalam menyalurkan dananya.

Berdasarkan tabel 5, Asuransi Staco Mandiri mengalami inefisiensi pada ketiga inputnya yaitu total aset, beban umum \& administrasi, dan pembayaran klaim. Selain itu, Asuransi Staco Mandiri juga diketahui telah melakukan inefisiensi pada salah satu outputnya yaitu pendapatan investasi. Dalam penelitian ini, total aset aktual Asuransi Staco Mandiri pada periode 2014, 2015 dan 2016 secara berturut-turut adalah sebesar Rp63.452 juta, Rp58.718 juta, dan Rp58.051 juta. Sedangkan total aset targetnya adalah Rp39.969 juta, Rp51.223 juta dan Rp53.684 juta. Secara rata-rata, Asuransi Staco Mandiri telah melakukan pemborosan secara berturut-turut sebesar Rp23.483 juta, Rp7.495, dan Rp4.367 juta. 
Tabel 5. Input-Output Asuransi Staco Mandiri pada Periode yang Tidak Efisien (dalam Jutaan Rupiah)

\begin{tabular}{ccccccc}
\hline \multirow{2}{*}{ Tahun } & \multicolumn{3}{c}{ Pendapatan Investasi } & \multicolumn{3}{c}{ Dana Tabarru } \\
\cline { 2 - 7 } & Target & Aktual & Selisih & Target & Aktual & Selisih \\
\hline 2014 & 2421 & 657 & 1764 & 4502 & 4502 & 0 \\
2015 & 1126 & 548 & 578 & 5932 & 5932 & 0 \\
2016 & 1973 & 477 & 1496 & 7532 & 7532 & 0 \\
\hline \multirow{2}{*}{ Tahun } & \multicolumn{7}{c}{ Total Aset } & \multicolumn{2}{c}{ Beban Umum \&Administrasi } \\
\cline { 2 - 7 } & Target & Aktual & Selisih & Target & Aktual & Selisih \\
\hline 2014 & 39969 & 63452 & -23483 & 1175 & 1865 & -690 \\
2015 & 51223 & 58718 & -7495 & 1495 & 1714 & -219 \\
2016 & 53684 & 58051 & -4367 & 1481 & 1602 & -121 \\
\hline \multirow{2}{*}{ Tahun } & \multicolumn{7}{c}{ Pembayaran Klaim } & Selisih \\
\hline 2014 & \multicolumn{7}{c}{ Target } & \multicolumn{3}{c}{ Aktual } & -2489 \\
2015 & 218 & 2707 & -1161 \\
2016 & 1341 & 2502 & -1780 \\
\hline
\end{tabular}

Sumber: Output DEAP 2.1 yang diolah kembali

Hal ini terjadi mungkin akibat Asuransi Staco Mandiri melakukan penanaman modal dalam aktiva tetap yang terlalu besar melebihi kebutuhan aktiva tetap yang dibutuhkan sebenarnya, sementara aktiva tetap akan mengalami penurunan nilai tiap periodenya. Hal ini sejalan dengan pendapat Khoirina (2017) yang menyatakan bahwa aktiva tetap mempunyai masa hidup lebih dari satu tahun. Dengan berlalunya waktu, aktiva tetap tersebut mungkin tidak dapat digunakan lagi sehingga dibutuhkan perbaikan yang cukup besar yang dalam hal ini tentu saja membutuhkan biaya yang tidak kecil. Dengan alasan tersebut, maka keputusan sehubungan dengan investasi modal dengan aktiva tetap perlu dipertimbangkan secara teliti dan sebaik-baiknya.

Input beban umum \& administrasi juga mengalami inefisiensi. Dimana beban umum \& administrasi aktualnya secara berturut-turut yaitu Rp1.865 juta, Rp1.714 juta dan Rp1.481juta. Sedangkan beban umum \& administrasi seharusnya atau targetnya adalah Rp1.175 juta, Rp1.495 juta dan Rp1.481 juta. Maka, dapat disimpulkan bahwa, Asuransi Staco Mandiri pada input beban umum \& administrasi mengalami pemborosan secara berturut-turut sebesar Rp690 juta, Rp219 juta, dan Rp121 juta.

Hal ini dapat terjadi akibat besarnya dana yang dikeluarkan Asuransi Staco Mandiri untuk membiayai segala sesuatu yang berkaitan dengan fungsi administrasi dan umum. Salah satunya membiayai fasilitas perusahaan pada karyawan, baik dari pemimpin perusahaan sampai dengan karyawan paling bawah. Beban ini tidak sebanding dengan kinerja karyawan.

Input pembayaran klaim juga mengalami pemborosan. Dimana pembayaran klaim aktualnya secara berturut-turut adalah Rp2.707 juta, Rp2.502 juta dan Rp2.498 juta. Adapun input pembayaran klaim seharusnya atau targetnya secara berturut-turut sebesar Rp218 juta, Rp1.341 juta, dan Rp718 juta. Asuransi Staco Mandiri mengalami pemborosan pada input pembayaran klaim secara berturut-turut sebesar Rp2489 juta, Rp1161 juta, dan Rp1780 juta. Pembayaran klaim aktual yang lebih besar dari targetnya menunjukkan bahwa Asuransi Staco Mandiri terlalu boros dalam melakukan pembayaran klaim. Hal ini bisa diakibatkan karena banyaknya pengajuan klaim dari para nasabah.

Pada output pendapatan investasi, Asuransi Staco Mandiri juga mengalami inefisiensi. Hal ini dapat ditunjukkan pada nilai aktual pendapatan investasi pada periode yang berturut-turut sebesar Rp657 juta, Rp548 juta dan Rp477 juta. Sedangkan nilai target yang pendapatan investasinya sebesar Rp2.421 juta, Rp1.126 juta, dan Rp1.973 juta. Agar pendapatan investasi menjadi efisien, maka harus dinaikkan sebesar Rp1.764juta, Rp578 juta, dan Rp1.496 juta. Hal ini dimungkinkan terjadi akibat Asuransi Staco Mandiri terlalu banyak dalam pembayaran klaimnya, sehingga pendapatan investasi tidak dapat mencapai targetnya.

Asuransi Umum Mega mengalami inefisiensi tiap periodenya. Inefisiensi ini diakibatnya dari pemborosan pada ketiga inputnya yaitu total aset, beban umum \& administrasi, dan pembayaran klaim. Asuransi Umum Mega juga mengalami inefisiensi pada outputnya yaitu pendapatan investasi pada periode 2016. Dalam penelitian ini, total aset aktualnya pada periode 2014, 2015, dan 2016 secara berturut-turut yaitu Rp137.216 juta, Rp159.565 juta, dan Rp166.456 juta. Sedangkan total aset seharusnya atau targetnya adalah Rp67.317 juta, Rp101.482 juta dan Rp103.170 juta. Jadi, Asuransi Umum Mega mengalami pemborosan pada total asetnya sebesar Rp69.899 juta, Rp58.083 juta dan Rp63.286 juta. 
Tabel 6: Input-Output Asuransi Umum Mega pada Periode yang Tidak Efisien (dalam Jutaan Rupiah)

\begin{tabular}{|c|c|c|c|c|c|c|}
\hline \multirow{2}{*}{ Tahun } & \multicolumn{3}{|c|}{ Pendapatan Investasi } & \multicolumn{3}{|c|}{ Dana Tabarru } \\
\hline & Target & Aktual & Selisih & Target & Aktual & Selisih \\
\hline 2014 & 4483 & 4483 & 0 & 7081 & 7081 & 0 \\
\hline 2015 & 6028 & 6028 & 0 & 12140 & 12140 & 0 \\
\hline 2016 & 8627 & 6358 & 2269 & 15414 & 15414 & 0 \\
\hline \multirow{2}{*}{ Tahun } & \multicolumn{3}{|c|}{ Total Aset } & \multicolumn{3}{|c|}{ Beban Umum \& Administrasi } \\
\hline & Target & Aktual & Selisih & Target & Aktual & Selisih \\
\hline 2014 & 67317 & 137216 & -69899 & 1526 & 3110 & -1584 \\
\hline 2015 & 101482 & 159565 & -58083 & 2482 & 3902 & -1420 \\
\hline 2016 & 103170 & 166456 & -63286 & 814 & 3695 & -2881 \\
\hline \multirow{2}{*}{ Tahun } & \multicolumn{6}{|c|}{ Pembayaran Klaim } \\
\hline & \multicolumn{2}{|c|}{ Target } & \multicolumn{2}{|c|}{ Aktual } & \multicolumn{2}{|c|}{ Selisih } \\
\hline 2014 & \multicolumn{2}{|c|}{3336} & \multicolumn{2}{|c|}{24960} & \multicolumn{2}{|c|}{-21624} \\
\hline 2015 & \multicolumn{2}{|c|}{6105} & \multicolumn{2}{|c|}{18449} & \multicolumn{2}{|c|}{-12344} \\
\hline 2016 & \multicolumn{2}{|c|}{2863} & \multicolumn{2}{|c|}{19092} & \multicolumn{2}{|c|}{-16229} \\
\hline
\end{tabular}

Sumber: Output DEAP 2.1. yang diolah kembali

Beban umum \& administrasi aktual secara berturut-turut yakni Rp3.110 juta, Rp3.902 juta dan Rp3.695 juta. Sementara beban umum \& administrasi seharusnya adalah Rp1.526 juta, Rp2.482 juta, danRp814juta. Jadi, Asuransi Umum Mega mengalami pemborosan sebesar Rp1.584 juta, Rp1.420 juta dan Rp2.881 juta.

Pembayaran klaim aktualnya secara berturut-turut sebesar Rp24.960 juta, Rp18.449 juta, dan Rp19.092 juta. Pembayaran klaim seharusnya atau targetnya adalah Rp3.336 juta, Rp6.105 juta, dan Rp2.863 juta. Jadi, Asuransi Umum Mega mengalami pemborosan pada pembayaran klaim sebesar Rp21.624 juta, Rp12.344 juta dan Rp16.229 juta.

Pada periode 2016, Asuransi Umum Mega tidak dapat mencapai target pada output pendapatan investasi. Padahal pada periode-periode sebelumnya selalu bisa mecapai targetnya. Pendapatan investasi aktual Asuransi Umum Mega pada periode 2016 yakni sebesar Rp.6.358 juta. Sedangkan pendapatan investasi seharusnya adalah Rp.8.627 juta. Jadi, Asuransi Umum Mega harus menaikkan pendapatan investasinya sebesar Rp2.269 juta.

Tabel 7. Input-Output Asuransi Sunlife pada Periode yang Tidak Efisien (dalam Jutaan Rupiah)

\begin{tabular}{ccccccc}
\hline \multirow{2}{*}{ Tahun } & \multicolumn{3}{c}{ Pendapatan Investasi } & \multicolumn{3}{c}{ Dana Tabarru } \\
2014 & 5218 & Aktual & Selisih & Target & Aktual & Selisih \\
2015 & 4471 & 4471 & 0 & 4718 & 4200 & 518 \\
2016 & 4137 & 4137 & 0 & 5719 & 5719 & 0 \\
\multirow{2}{*}{ Tahun } & \multicolumn{5}{c}{ Total Aset } & \multicolumn{4}{c}{ Beban Umum \& Administrasi } \\
\cline { 2 - 7 } & Target & Aktual & Selisih & Target & Aktual & Selisih \\
\hline 2014 & 74380 & 95643 & -21263 & 7790 & 25453 & -17663 \\
2015 & 63940 & 90490 & -26550 & 3393 & 39057 & -35664 \\
2016 & 69920 & 111651 & -41731 & 1265 & 55465 & -54200 \\
\hline \multirow{2}{*}{ Tahun } & \multicolumn{7}{c}{ Pembayaran Klaim } \\
\cline { 2 - 7 } 2014 & Target & \multicolumn{3}{c}{ Aktual } & \multicolumn{3}{c}{ Selisih } \\
2015 & 2059 & 2648 & -589 \\
2016 & 1787 & 3634 & -1847 \\
\hline
\end{tabular}

Sumber: Output DEAP 2.1. yang diolah kembali

Asuransi Sunlife mengalami inefisiensi tiap periodenya. Penyebab ketidakefisien pada Asuransi Sunlife yaitu ketiga inputnya (total aset, beban umum \& administrasi dan pembayaran klaim). Pada periode 2014 dan 2014 juga mengalami inefisiensi pada salah satu outputnya yaitu dana tabarru'. Hal ini bisa dilihat pada tabel 4.6 di atas. Total aset aktual pada periode 2014, 2015, dan 2016 secara berturut-turut adalah Rp95.643 juta, Rp90.490 juta dan Rp111.651 juta. Adapun total aset seharusnya atau targetnya adalah Rp74.380 juta, Rp63.940 
juta, dan Rp69.920 juta. Asuransi sunlife mengalami pemborosan pada total asetnya sebesar Rp21.263 juta, Rp26.550 juta, dan Rp41.731 juta.

Beban umum \& administrasi aktual Asuransi Sunlife secara berturut-turut sebesar Rp25.453 juta, Rp39.057 juta, danRp55.465 juta. Beban umum \& administrasi seharusnya atau targetnya yaitu Rp7.790 juta, Rp3.393 juta danRp1.265 juta. Asuransi Sunlife mengalami pemborosan pada beban umum \& administrasi sebesar Rp17.663 juta, Rp35.664 juta, dan Rp54.200 juta.

Asuransi Sunlife mengalami inefisiensi pada input pembayaran kalim. Pembayarn klaim aktual secara berturut-turut yaitu Rp2.648 juta, Rp3.634 juta danRp7.719 juta. Pembayaran klaim seharusnya atau targetnya yakni Rp2.059 juta, Rp1.787 juta, dan Rp1.396 juta. Jadi, Asuransi Sunlife mengalami pemborosan pada pembayaran klaim sebesar Rp589 juta, Rp1.847 juta danRp6.323 juta. Asuransi Sunlife juga mengalami inefisiensi pada salah satu outputnya yaitu dana tabarru'. Inefisiensi ini terjadi pada periode 2014. Dana tabarru' aktual pada tahun 2014 sebesar Rp4.200 juta. Dana tabarru' seharusnya atau targetnya yakni sebesar Rp4.718 juta.

Peningkatan efisiensi harus dilakukan oleh Asuransi Sunlife. Ketidakefisien ini disebabkan karena belum tercapainya target output dana tabrru'. Maka untuk mencapai output yang maksimal, Asuransi Sunlife harus menaikkan dana tabarru' pada sebesar Rp518 juta.

\section{Kesimpulan}

Dari penelitian dan pembahasan yang telah dijelaskan sebelumnya, maka penelitian ini dapat diambil kesimpulan bahwa analisis tingkat efisiensi asuransi umum unit syariah periode 2014-2016 dengan menggunakan metode DEA, diketahui nilai rata-rata efisiensi pada masing-masing asuransi yaitu Asuransi Central Asia 76,4\%, Asuransi Adira Finance 76,2\%, Asuransi Jasa Raharja 100\%, Asuransi Bringin Sejahtera Artha makmur 100\%, Asuransi Staco Mandiri 80,9\%, Asuransi Tugu Pratama 80,3\%, Asuransi Umum Mega 58,2\%, Asuransi Bumi Putera Muda 96,3\%, dan Asuransi AXA Mandiri 89,4\%.

Analisis tingkat efisiensi asuransi jiwa unit syariah periode 2014-2016 dengan menggunakan metode DEA, diketahui nilai rata-rata efisiensi pada masing-masing asuransi yaitu Asuransi Great Eastern 100\%, Asuransi Manulife 100\%, Asuransi Panindai-Ichi Life 100\%, Asuransi Prudential 100\%, Asuransi Sunlife 70,4\%, Asuransi Tokio Marine 92,8\%, Asuransi Central Asia Raya Life 90\%, dan Asuransi Avrist 88,1\%.

Analisis tingkat efisiensi asuransi syariah selama periode 2014-2016 pada seluruh sampel, menunjukkan bahwa ada empat asuransi yang tidak efisien yakni Asuransi Central Asia, Asuransi Staco Mandiri, Asuransi Umum Mega dan Asuransi Sunlife. Keempat asuransi tersebut tidak dapat mencapai efisiensi $100 \%$ selama tiga periode penelitian. Tidak efisian perusahaan asuransi syariah ini disebabkan oleh beberapa hal diantaranya: beban umum \& administrasi, pembayaran klaim, pendapatan investasi, penanaman modal, dan penghimpunan dana tabarru'.

\section{Daftar Pustaka}

Abidin, Z. \& Cabanda, E. (2012). Efficiency of Non-Life Insurance in Indonesia. Journal of Economics, Business and Accountancy Ventura. 14 (3), 197-202.

Al-Amri K. 2015. Takaful Insurance Efficiency in the GCC Countries. Humanomics. 31 (3), 344-353.

Antonio, M. S., Ali, M. M., \& Akbar, N. (2013). A Comparative Analysis of Efficiency of Takaful and Conventional Insurance in Malaysia. Hamdan Bin Mohammed e-University Journals.

Farrell, M. (1957). The measurement of productive efficiency. Journal of the Royal Statistical Society, 12 (3), 253-290.

Karim, A., A. (2007). Ekonomi Mikro Islami Edisi Ketiga. Jakarta: Rajawali Pers.

Khoirina, I. (2017). Analisis tingkat efisiensi perbankan syariah di indonesia tahun 2014-2016 dengan metode data envelopment analysis dan faktor-faktor yang mempengaruhinya. Skripsi tidak dipublikasikan. Yogyakarta: UIN Sunan Kalijaga.

Muharam, H., \& Pusvitasari, R. (2007). Analisis Perbandingan Efisiensi Bank Syariah di Indonesia Dengan Metode Data Envelopment Analysis. Jurnal Ekonomi dan Bisnis Islam, 2(3), 86-87.

Purwanti, A. (2016). Analisis Perbandingan Efisiensi pada Industri Asuransi Umum Syariah dan Konvensional di Indonesia dengan Pendekatan Two-Stage Data Envelopment Analysis (DEA). Skripsi tidak dipublikasikan. Semarang: Universitas Diponegoro. 
Purwanto, R. (2011). Analisis Perbandingan Efisiensi Bank Umum Konvensional (BUK) dan Bank Umum Syariah (BUS) dengan Metode Data Envelopment Analysis (DEA) (Periode 2006-2010). Skripsi tidak dipublikasikan. Semarang: Universitas Diponegoro.

Purwantoro, R, Nugroho dan Siswandi, E., (2006), Pengolahan Data Skala Terbatas dengan Metoda Data Envelopment Analysis (DEA): Studi Kasus Efektivitas Proses Peluncuran Produk Baru, Makalah Manajemen Usahawan Indonesia, Jakarta; Universitas Indonesia.

Saad. NM, Majid SA, Yusof R.M, Duasa J, Rahman ARA. (2007). Measuring Efficiency of Insurance and Takaful Companies in Malaysia using Data Envelopment Analysis (DEA). Review of Islamic Economics. 11 (1), 5-26.

Sabiti, M.B., Effendi, J., dan Novianti, T., (2017). Efisiensi Asuransi Syariah di Indonesia dengan Pendekatan Data Envelopment Analysis, Jurnal Al-Muzara'ah. 5(1), 69-87.

Sutawijaya, A \& Lestari, E.P. (2009). Efisiensi Teknik Perbankan Indonesia pascakrisis ekonomi: Sebuah studi empiris penerapan model DEA. Jurnal Ekonomi Pembangunan, 10 (1), 49-67.

Tuffahati, H., Mardian, S., \& Suprapto, E (2017). Pengukuran Efisiensi Asuransi Syariah dengan Data Envelopment Analysis (DEA). Jurnal Akuntansi dan Keuangan Islam 4 (1), 1-24. 